\title{
Evaluation of Some Antibiotics Against Pathogenic Bacteria Isolated from Infant Foods in North Africa
}

\author{
M. Shadlia-Matug ${ }^{1}$, K.E. Aidoo*,1, A.A. Candlish ${ }^{1}$ and A.M. Elgerbi ${ }^{2}$ \\ ${ }^{I}$ School of Biological and Biomedical Sciences, Glasgow Caledonian University, Cowcaddens Road, Glasgow G4 OBA, \\ $U K$ \\ ${ }^{2}$ Department of Food Technology, Sebha University, Faculty of Engineering and Technology, Brack Ashati, P.O. Box \\ 68, Libya
}

\begin{abstract}
Eighty four samples of commercial infant foods in Libya were examined for microbiological quality. Bacillus cereus, B. stearothermophilus, B. licheniformis, Staphylococcus xylosus, S.lentus, Enterobacter sakazakii, E. aerogenes were isolated from the samples. Over $64.3 \%$ of the samples contained high counts of Bacillus $\operatorname{spp}\left(\geq 2 \log _{10} \mathrm{CFU} / \mathrm{g}\right)$, $42.9 \%$ Staphylococcus spp ( $\geq 2 \log _{10} \mathrm{CFU} / \mathrm{g}$ ) and $26.3 \%$ Enterobacteriaceae ( $\left.\geq 2 \log _{10} \mathrm{CFU} / \mathrm{g}\right)$. The moulds isolated were mainly of the genera, Aspergillus and Penicillium. In relation to antibiotic resistance Bacillus spp showed the highest level of resistance to bacittracin $(63.6 \%)$, ampicillin $(54.5 \%)$, cephalosporin $(36.4 \%)$, penicillin $(18.1 \%)$ and nalidixine acid (18.2\%). Corresponding values for Staphylococcus spp were bacitracin 60\%, erythromycin 30\%, penicillin 30\%, cephalosporin $10 \%$, nalidixic acid $10 \%$ and ampicillin 10\%, respectively. Enterobacteriaceae strains were resistant to bacitracin (100\%), erythromycin (62.5\%), ampicillin (37.5\%), cephalosporin (25\%) and nalidixine acid (12.5\%). Bacillus spp, Staphylococcus spp and Enterobacteriaceae were susceptible to chloramphenicol, kanamycin, gentamicin and streptomycin.
\end{abstract}

Keywords: Infant food, Bacillus spp., enterobacteriaceae, Staphylococcus spp., antimicrobial resistance.

\section{INTRODUCTION}

Contamination of infant food by microorganisms and natural toxins such as enterotoxins and mycotoxins has been the most common problem resulting in several outbreaks of diseases [1-4]. In most studies reviewed, contamination of infant food formula by pathogenic microorganisms at some points during production resulted in several outbreaks of diseases worldwide. The use of infant formula in developing countries has caused higher rates of diarrhoeal morbidity and mortality, possibly because contaminated water is often used to prepare infant formula and because the high nutrient contents of infant formula provide a good growth medium for bacterial pathogens [5].

Lehner et al. [6] reported that when reconstituted formula was stored for about $10 \mathrm{~h}$ the bacterial count increased from $<10^{1}$ to $10^{7}$ CFU/100 ml. Schmitt et al. [7] reported two cases of food poisoning that resulted from the consumption of powdered milk products. Muytjens et al. [8] and Forsythe [9] reported the isolation of the Enterobacteriaceae from powdered infant formula. The Enterobacteriaceae isolated included Enterobacter agglomerans, E. cloacae, E. sakazakii, Citrobacter koseri and Klebsiella oxytoca.

In New Zealand, there were four identified cases of $E$. sakazakii infection in premature babies - one in 1986, two in 1991 and one in 2004 have been linked to consumption of infant formula [10,11]. Enterobacter sakazakii causes major

*Address correspondence to this author at the School of Biological and Biomedical Sciences, Glasgow Caledonian University, Cowcaddens Road, Glasgow G4 0BA, UK; E-mail: K.Aidoo@gcal.ac.uk infections especially among neonates $[2,12]$. Recently the Food Standards Agency, UK reported on the presence of $E$. sakazakii in a Ugandan baby food product [13].

Improperly stored cereal-based product may also become contaminated with fungi and under conditions of high humidity, poor ventilation and warm temperature growth of certain fungi may result in the production of toxic substances (mycotoxins) which are known to be carcinogenic. Studies on occurrence of microorganisms and potential microbial metabolites in baby food and feed formula have received little attention particularly in developing countries.

The aim of the present study was to evaluate the microbiological contamination of commercial infant food available in North Africa and to determine the susceptibility of the isolated bacteria against some antibiotics.

\section{MATERIALS AND METHODS}

\section{Samples and Media}

Eighty four samples of baby food consumed by Libyan infants were collected from several local sources including retailers, factories and stores. Samples which consisted of imported and locally produced products were stored dry at room temperature $\left(22 \pm 2^{\circ} \mathrm{C}\right)$ and examined to determine their level of contamination. The samples contained rice flour, wheat flour, mixed grain cereal contained, wheat, rice, barley, and oat flour, skimmed milk powder or whole milk powder and in various combination. The samples were examined for bacteria species such as Bacillus spp, Staphylococcus spp, Enterobacteriaceae and fungi. Standard methods were used for isolation, enumeration and identification of bacteria and fungi $[14,15]$. 
Table 1. Total Bacterial and Fungal Counts and Occurrence of Bacillus spp., Enterobacteriaceae and Staphylococcus spp. in Infant Foods

\begin{tabular}{|c|c|c|c|c|c|c|c|}
\hline \multirow{2}{*}{$\begin{array}{l}\text { Product } \\
\text { Number }\end{array}$} & \multirow{2}{*}{$\begin{array}{l}\text { Number of } \\
\text { Product } \\
\text { Examined }\end{array}$} & \multirow[t]{2}{*}{ Main Ingredients } & \multirow{2}{*}{$\begin{array}{l}\text { Range } \log _{10} \\
\text { CFU/g of Total } \\
\text { Count }\end{array}$} & \multirow{2}{*}{$\begin{array}{l}\text { Range } \log _{10} \\
\text { CFU/g of Fungi }\end{array}$} & \multicolumn{3}{|c|}{ Number and Percentage of Samples Positive for } \\
\hline & & & & & Bacillus spp. & Enterobacteriaceae & $\begin{array}{l}\text { Staphylococcus } \\
\text { spp. }\end{array}$ \\
\hline $\mathrm{P} 1$ & 8 & Rice flour, maltodextrin. & $<1.0-3.67$ & $1.0-3.67$ & $3(37.5 \%)$ & ND & $4(50 \%)$ \\
\hline $\mathrm{P} 2$ & 3 & Rice flour, malt, maltodextrin. & $<1.0-3.43$ & $<1.0-2.63$ & $1(33.3 \%)$ & ND & ND \\
\hline P3 & 1 & Wheat flour, sugar, vegetable. & 3.81 & 3.0 & $1(100 \%)$ & ND & ND \\
\hline $\mathrm{P} 4$ & 5 & Cereals with milk. & $<1.0-5.28$ & $<1.0-3.3$ & $3(100 \%)$ & ND & $2(40 \%)$ \\
\hline P5 & 4 & Rice flour. & $<1.0-3.91$ & $<1.0-2.52$ & $3(75 \%)$ & $2(50 \%)$ & $2(50 \%)$ \\
\hline P6 & 7 & $\begin{array}{l}\text { Wheat flour, banana, skimmed } \\
\text { milk powder, whole milk } \\
\text { powder, malt extract, milk fat. }\end{array}$ & $<1.0-3.54$ & $<1.0-3.4$ & $3(42.9 \%)$ & $2(28.6 \%)$ & $3(42.9 \%)$ \\
\hline P7 & 3 & $\begin{array}{l}\text { Wheat flour, vegetables (carrot, } \\
\text { tomato, peas, spinach), } \\
\text { skimmed milk powder, malt } \\
\text { extract, milk fat. }\end{array}$ & $<1.0-6.43$ & $2.36-3.43$ & $2(67 \%)$ & $1(33.3 \%)$ & $3(100 \%)$ \\
\hline P8 & 7 & Wheat flour, corn starch. & $<1.0-3.39$ & $<1.0-2.82$ & $4(57.1 \%)$ & ND & ND \\
\hline P9 & 9 & $\begin{array}{l}\text { Milk, cereal, orange and honey, } \\
\text { skimmed milk, wheat flour. }\end{array}$ & $<1.0-4.06$ & $<1.0-3.32$ & $6(66.7 \%)$ & $5(55.6 \%)$ & $6(66.7 \%)$ \\
\hline P10 & 3 & $\begin{array}{l}\text { Wheat flour, skimmed milk } \\
\text { powder, banana, malt extract, } \\
\text { milk fat. }\end{array}$ & $2.69-5.81$ & $2.69-3.39$ & $3(100 \%)$ & ND & $2(66.6 \%)$ \\
\hline P11 & 3 & $\begin{array}{l}\text { Skimmed milk, wheat flour, } \\
\text { fruit concen- } \\
\text { trates(orange,banana, lemon). }\end{array}$ & $<1.0-3.82$ & $<1.0-2.83$ & $2(66.6 \%)$ & $1(33.3 \%)$ & $1(33.3 \%)$ \\
\hline P12 & 1 & Rice flour. & 3.57 & 2.91 & $1(100 \%)$ & ND & $1(100 \%)$ \\
\hline P13 & 9 & Wheat flour, nuts. & $1.89-5.58$ & $<1.0-3.57$ & $5(55.6 \%)$ & $4(80 \%)$ & $2(22.2 \%)$ \\
\hline $\mathrm{P} 14$ & 2 & Rice flour, nuts. & $2.75-2.79$ & $2.43-2.80$ & $2(100 \%)$ & $1(50 \%)$ & $1(50 \%)$ \\
\hline $\mathrm{P} 15$ & 5 & Rice flour. & $2.44-4.41$ & $0.0-3.64$ & $3(60 \%)$ & $1(20 \%)$ & $1(20 \%)$ \\
\hline P16 & 14 & Ground nuts and mixed grains. & $2.91-5.34$ & $0.0-3.43$ & $8(57.1 \%)$ & $6(42.9 \%)$ & $6(42.9 \%)$ \\
\hline Total & 84 & & & & $61.9 \%$ & $27.4 \%$ & $40.5 \%$ \\
\hline
\end{tabular}

$\mathrm{ND}=$ not detected.

Samples were reconstituted in maximum recovery diluents (MRD). Total aerobic bacterial counts were determined using plate count agar. Bacillus cereus was isolated and enumerated using Bacillus cereus selective agar (PEMBA) and Bacillus cereus agar base. Coliforms and Enterobacteriaceae were isolated and enumerated using Violet red bile glucose (VRBG) agar. Enterobacter sakazakii was isolated by using Chromocult ${ }^{\circledR}$ Enterobacter sakazakii agar. Staphylococcus spp was isolated and enumerated using BairdParker agar. Selective enrichment broth (RV) and XLD were used for isolation of Salmonella. spp. Moulds and yeast were isolated and enumerated using malt extract agar (MEA) and potato dextrose agar (PDA). All media and diluents were purchased from Oxoid (Basingstoke, UK).

\section{Antimicrobial Compounds Tested on Isolates}

The following antimicrobial agents: penicillin, cephalosporin, bacitracin, polymxin B, streptomycin, tetracycline and gentamicin were purchased from Sigma, (Dorset, UK) and their minimum inhibitory concentrations (MIC) evaluated against some of the bacteria isolated.

Studies on antimicrobial resistance of the isolates were carried out with the following antibiotic test discs purchased from Oxoid (Basingstoke, UK): penicillin G10 units, cephalosporin $30 \mu \mathrm{g}$, bacitracin 10units, streptomycin $10 \mu \mathrm{g}$, tetracycline $30 \mu \mathrm{g}$, gentamicin $10 \mu \mathrm{g}$, erythromycin $15 \mu \mathrm{g}$, ampicillin $10 \mu \mathrm{g}$, chloramphenicol $30 \mu \mathrm{g}$, kanamycin $10 \mu \mathrm{g}$ and naldixic acid $30 \mu \mathrm{g}$.

\section{Cultivation, Enumeration and Identification of Microor- ganisms}

Sterile maximum recovery diluent $(225 \mathrm{ml})$ was added to $25 \mathrm{~g}$ of the sample, and then mixed in a stomacher for $60 \mathrm{~s}$. The bacteria and fungi present were isolated and enumerated by plating out in a serial dilution for each sample in triplicate onto PCA, PEMBA, Baird-Parker agar, XLD agar and VRBG agar for bacteria and, MEA and PDA for fungi. The plates were incubated at $37^{\circ} \mathrm{C}$ for $48 \mathrm{~h}$ and $25^{\circ} \mathrm{C}$ for 5 days respectively. The results were reported as the percentage of the samples positive for each organism.

Colonies obtained on the culture media were also examined for the following properties: Gram staining, catalase reactions, haemolytic reaction and motility. In addition to these tests each isolate was confirmed using the API $20 \mathrm{E}$, API staph and API $50 \mathrm{CH}$ tests (Biomerieux, Basingstoke, UK). Fungal isolates were identified according to the method described by Samson et al. [15] size, colour and morphology of colonies on media were recorded after incubation at $25^{\circ} \mathrm{C}$ for 5 days.

\section{Inhibition Assays}

Determination of MIC and susceptibility of the isolated bacteria to various antibiotics was performed following $\mathrm{Na}-$ tional Committee for Clinical Laboratory Standard recommendations (NCCLS, 1993) [16]. Thirty one bacterial strains were used; twenty eight were isolated from the samples and three were type cultures used for control purposes (Staphylo- 
coccus aureus, NCTC6571 and E. coli, NCTC9001 obtained from the National Collection of Typed Cultures and E. sakazakii NCIMB 8272 purchased from the National Collection of Industrial and Marine Bacteria Ltd, Aberdeen, Scotland).

Bacterial isolates were cultivated in nutrient broth at $35^{\circ} \mathrm{C}$ for $2-5 \mathrm{~h}$ until an absorbance of 0.2 was obtained at wavelength, $450 \mathrm{~nm}$, and equivalent to cell density of $10^{8}$ $\mathrm{CFU} / \mathrm{ml}$ as described by Carmen et al. [17] with some modifications. Swabs were dipped into standardised bacterial suspension and then streaked in three directions over the surface of plate agar and allowed to dry for $5 \mathrm{~min}$ before the discs $(13 \mathrm{~mm})$ and antibiotics were applied. An aliquot of $0.1 \mathrm{ml}$ antibiotic was placed onto each disc. The inhibition zones $(\mathrm{mm})$ were recorded after incubation at $35^{\circ} \mathrm{C}$ for $24 \mathrm{~h}$.

\section{Data Analyses}

Tests were carried out in triplicates. Colonies were counted and expressed as $\log _{10} \mathrm{CFU} / \mathrm{g}$. Mean and SD was calculated using Microsoft Office Excel 2003 software (Microsoft Corporation, Redmont, Washington, USA). Susceptibility test results were considered when diameter for strains was within the ranges accepted by the National Committee for Clinical Laboratory Standard.

\section{RESULTS AND DISCUSSION}

The general microbiological quality of the infant food and feed samples is given in Table 1 . The total counts varied over the range $\leq 1.0$ to $6.4 \log _{10} \mathrm{CFU} / \mathrm{g}$ with the mean total count of $3.4 \log _{10} \mathrm{CFU} / \mathrm{g}$. Of the eighty four samples examined, $60 \%$ were considered microbiologically satisfactory because the total aerobic mesophilic count were $\leq 4.0 \log _{10}$ $\mathrm{CFU} / \mathrm{g}$ [18]. Nearly $10 \%$ (8) of the samples, were deemed unsatisfactory for infant consumption because they contained a total viable count of $\geq 5.0 \log _{10} \mathrm{CFU} / \mathrm{g}$ powder. The total mould count in most samples was equal to or less than 3.7 $\log _{10} \mathrm{CFU} / \mathrm{g}$. Average counts of Bacillus. spp, Staphylococcus. spp and Enterobacteriaceae were 4.4, 4.5 and $3.8 \log _{10}$ $\mathrm{CFU} / \mathrm{g}$ respectively.

Occurrence of Bacillus spp. Enterobacteriaceae and Staphylococcus spp. in the samples was $61.9 \%, 27.4 \%$ and $40.5 \%$ respectively. Of the $10(60 \%)$ strains of Bacillus spp. were identified as Bacillus cereus. More than $64.3 \%$ of the samples contained high count of Bacillus spp. $\left(\geq 2 \log _{10}\right.$ $\mathrm{CFU} / \mathrm{g}$ ). Becker et al. [19] reported that when samples of infant food distributed in 17 countries were examined for $B$. cereus, $54 \%$ of them were contaminated with $B$. cereus with levels of $\leq 6 \times 10^{2}$ viable cells/g, much lower than results found in this study. Dried milk products, such as milk powder, infant milk formula and infant cereal products, contaminated with $B$. cereus should be considered as potential vehicle for foodborne B.cereus disease [19, 20]. These products often contain high level of carbohydrates (starch, sucrose or lactose) and minerals which can promote proliferation and enterotoxin production when they are reconstituted and held at ambient temperature for extended periods, potentially even at refrigeration temperature [21-23]. Bacillus spp isolated were identified as B. cereus, B. licheniformis, Geobacillus stearothermophilus, B. subtilis, Brevi. Laterosporus and some unidentified Bacillus spp. isolated were similar to that reported by Rowan et al. [21].

In this study, it was found that more than $26.3 \%$ of the samples contained Enterobacteriaceae ( $\geq 2 \log _{10}$ CFU/g).
Salmonella was not present in any of the samples tested. Other studies showed occurrence of Enterobacteriaceae in different types of infant food products although Salmonella spp were not detected in any of the infant samples examined [8, 10, 24]. Iversen and Forsythe [9] also reported the absence of Salmonella. spp in powdered infant milk formula. Other pathogens such as Listeria monocytogenes and Salmonella spp have been shown to be able to tolerate the spray drying, a process used in the production of a number of infant food formulae [25]. Enterobacteriaceae isolates from the products examined were identified as $K$. pneumoniae, $E$. aerogenes, E. sakazakii, K. oxytoca, E. coli, Aeromonas hydrophila, E. cancerogenus. Two of the samples which showed the presence of $E$. sakazakii were both manufactured in North Africa. Occurrence of E. sakazakii in formula and infant feed has been reported $[8,26]$.

Over $42 \%$ of the samples contained Staphylococcus spp ( $\geq 2 \log _{10} \mathrm{CFU} / \mathrm{g}$ ). This is in agreement with the study by Benda and Vyletelova [27]. They reported that S. aureus counts from milk samples collected from a baby food factory were 2 to $3 \log _{10} \mathrm{CFU} / \mathrm{g}$. Also Silvia, et al. [28] reported isolating $S$. aureus from 11 samples of milk with counts greater than $10^{5} \mathrm{CFU} / \mathrm{g}$. Sugimoto, et al. [29] investigated raw and powdered milk samples collected from various milk processing factories for microbial quality and found that viable counts in raw milk ranged from $10^{3}$ to $10^{6} \mathrm{CFU} / \mathrm{ml}$ and $<10$ to $10^{3} \mathrm{CFU} / \mathrm{g}$ in powdered samples. Staphylococcus aureus and B. cereus accounted for 79 and $26.3 \%$ of the isolates respectively. They isolated 143 strains of $S$. aureus and $13(9.1 \%), 5(3.5 \%)$ and $2(1.4 \%)$ of the strains produced enterotoxins B, A and $\mathrm{C}$ respectively. Staphylococci are among the most significant pathogens that cause wide spectrum of diseases in both humans and animals. Staphylococcus aureus is capable of producing enterotoxins which are resistant to most cooking temperature [30]. The toxin is only produced in sufficient quantities when the bacterial numbers reach $10^{5}$ to $10^{8}$ cells/g or $\mathrm{ml}$ of contaminated foods (Letertre, et al. [31]. The 27 isolated strains of Staphylococcus spp. were identified as Derma nishinomiyaen, S. xylosus, Kocuria varians, S. lentus, Kytococ sedenarius, and Kocuria rosea.

Sixty isolates comprising Bacillus spp., Staphylococcus spp. and Enterobacteriaceae were identified by API system (Biomerieux Limited, Basingstoke, UK). All identified isolates were tested for their resistance to antibiotics (Tables 24).

Based on MIC break point analysis, a high percentage of bacterial resistance was observed among Gram positive bacteria with some of the antimicrobials tested. For instance $80 \%$ of Bacillus spp. strains were resistant to cephalosporin (MIC $\geq 2.048 \mu \mathrm{g} / \mathrm{ml}$ ), $60 \%$ of strains were resistant to penicillin (MIC ranged $0.128-0.256 \mu \mathrm{g} / \mathrm{ml}$ ), while $40 \%$ of strains were resistant to bacitracin (MIC ranged 0.128-1.024 $\mu \mathrm{g} / \mathrm{ml}$ ). Antibiotic susceptibility data with Bacillus spp. confirm previous reports that Gram positive bacteria are generally resistant to penicillin and cephalosporin [32-34]. The majority of the Gram positive strains were found to be resistant to penicillin, bacitracin and cephalosporin, probably in part by means of $\beta$ - lactamase production [34]. For other antimicrobial tested, the tetracycline MIC was $0.128 \mu \mathrm{g} / \mathrm{ml}$ and gentamicin MIC was $0.0002 \mu \mathrm{g} / \mathrm{ml}$ for Bacillus spp. 
Table 2. Minimum Inhibitory Concentration (MIC) of Some Antibiotics for Bacillus spp. Isolated from Infant Foods

\begin{tabular}{|c|c|c|c|c|c|}
\hline Species & \multicolumn{5}{|c|}{$\operatorname{MIC}(\mu \mathrm{g} / \mathrm{ml}){ }^{\mathrm{b}} /$ Diameter zone $(\mathrm{mm} \pm \mathrm{SD})^{\mathrm{a}}$} \\
\hline Brevi. laterosporus & $0.002^{\mathrm{a}} /(22 \pm 0.0)^{\mathrm{b}}$ & $0.016^{\mathrm{a}} /(21 \pm 0.5)^{\mathrm{b}}$ & - & $0.032^{\mathrm{b}} /(13 \pm 0.3)^{\mathrm{b}}$ & $0.064^{\mathrm{a}}(18 \pm 0.13)^{\mathrm{b}}$ \\
\hline Bacillus.spp & $0.001^{\mathrm{a}} /(23 \pm 0.17)^{\mathrm{b}}$ & - & $2.048^{\mathrm{a}} /(20 \pm 0.44)^{\mathrm{b}}$ & $0.512^{\mathrm{a}} /(20 \pm 0.0)^{\mathrm{b}}$ & $0.00025^{\mathrm{a}}(28 \pm 0.1)^{\mathrm{b}}$ \\
\hline B. cereus $(1)$ & $0.002^{\mathrm{a}} /(17 \pm 0.0)^{\mathrm{b}}$ & $0.016^{\mathrm{a}} /(15 \pm 0.1)^{\mathrm{b}}$ & - & $0.016^{\mathrm{a}} /(1.5 \pm 0.22)^{\mathrm{b}}$ & $0.256^{\mathrm{a}} /(15 \pm 0.1)^{\mathrm{b}}$ \\
\hline B. cereus (3) & $0.002^{\mathrm{a}} /(19 \pm 0.2)^{\mathrm{b}}$ & $0.128^{\mathrm{a}} /(20 \pm 0.1)^{\mathrm{b}}$ & - & $1.024^{\mathrm{a}} /(16 \pm 0.0)^{\mathrm{b}}$ & $0.256^{\mathrm{a}}(18 \pm 0.0)^{\mathrm{b}}$ \\
\hline Geobacillus stearothermophilus & $0.001^{\mathrm{a}} /(15 \pm 0.0)^{\mathrm{b}}$ & $0.008^{\mathrm{a}} /(16 \pm 0.1)^{\mathrm{b}}$ & $2.048^{\mathrm{a}} /(16 \pm 0.35)^{\mathrm{b}}$ & $0.128^{\mathrm{a}} /(15 \pm 0.33)^{\mathrm{b}}$ & $0.004^{\mathrm{a}}(20 \pm 0.18)^{\mathrm{b}}$ \\
\hline B. cereus (4) & $0.005^{\mathrm{a}} /(15 \pm 0.5)^{\mathrm{b}}$ & $0.032^{\mathrm{a}} /(16 \pm 0.0)^{\mathrm{b}}$ & - & $0.032^{\mathrm{a}} /(16 \pm 0.0)^{\mathrm{b}}$ & $0.256^{\mathrm{a}} /(16 \pm 0.1)^{\mathrm{b}}$ \\
\hline B. cereus (5) & $0.0002^{a} /(17 \pm 0.0)^{b}$ & $0.016^{\mathrm{a}} /(17 \pm 0.3)^{\mathrm{b}}$ & $2.048^{\mathrm{a}} /(15 \pm 0.0)^{\mathrm{b}}$ & $0.032^{\mathrm{a}} /(15 \pm 0.1)^{\mathrm{b}}$ & $0.128^{\mathrm{a}}(18 \pm 0.1)^{\mathrm{b}}$ \\
\hline
\end{tabular}

$\mathrm{a}=\mathrm{MIC}(\mu \mathrm{g} / \mathrm{ml}), \mathrm{b}=$ Diameter Zone $(\mathrm{mm} \pm \mathrm{SD}),-$ = no effect.

Table 3. Minimum Inhibitory Concentration (MIC) of some Antibiotics for Staphylococcus spp. and Micrococcus spp. Isolated from Infant Foods

\begin{tabular}{|c|c|c|c|c|c|}
\hline \multirow{2}{*}{ Species } & \multicolumn{5}{|c|}{ MIC $(\mu \mathrm{g} / \mathbf{m l})^{\mathrm{a}} /$ Diameter zone $(\mathbf{m m})^{\mathrm{b}}$} \\
\cline { 2 - 6 } & Gentamicin & Tetracycline & Cephalosporin $^{*}$ & Bacitracin $^{*}$ & Penicillin \\
\hline \hline S. aureus $($ NCTC 6571$)$ & $0.002^{\mathrm{a}} /(19 \pm 0.4)^{\mathrm{b}}$ & $0.016^{\mathrm{a}} /(25 \pm 0.0)^{\mathrm{b}}$ & $0.512^{\mathrm{a}} /(18 \pm 1.02)^{\mathrm{b}}$ & $0.064^{\mathrm{a}} /(15 \pm 0.0)^{\mathrm{b}}$ & $0.004^{\mathrm{a}} /(40 \pm 0.76)^{\mathrm{b}}$ \\
\hline S. xylosus & $0.0005^{\mathrm{a}} /(16 \pm 0.0)^{\mathrm{b}}$ & $0.016^{\mathrm{a}} /(21 \pm 0.3)^{\mathrm{b}}$ & $0.512^{\mathrm{a}} /(19 \pm 0.0)^{\mathrm{b}}$ & $0.256^{\mathrm{a}} /(18 \pm 0.54)^{\mathrm{b}}$ & $0.064^{\mathrm{a}} /(17 \pm 0.57)^{\mathrm{b}}$ \\
\hline S. lentus & $0.001^{\mathrm{a}} /(15 \pm 0.1)^{\mathrm{b}}$ & $0.008^{\mathrm{a}} /(24 \pm 0.8)^{\mathrm{b}}$ & $0.512^{\mathrm{a}} /(22 \pm 0.2)^{\mathrm{b}}$ & $0.008^{\mathrm{a}} /(21 \pm 0.42)^{\mathrm{b}}$ & $0.0002^{\mathrm{a}} 5 /(23 \pm 1.02)^{\mathrm{b}}$ \\
\hline Kytococ. Sedenarius & $0.0005^{\mathrm{a}} /(18 \pm 0.5)^{\mathrm{b}}$ & $0.002^{\mathrm{a}} /(13 \pm 0.0)^{\mathrm{b}}$ & $0.512^{\mathrm{a}} /(34 \pm 0.7)^{\mathrm{b}}$ & $0.0005^{\mathrm{a}}(13 / \pm 0.61)^{\mathrm{b}}$ & $0.00025^{\mathrm{a}} /(30 \pm 0.9)^{\mathrm{b}}$ \\
\hline Derma.nishinomiyaen & $0.0005^{\mathrm{a}} /(16 \pm 0.36)^{\mathrm{b}}$ & $0.032^{\mathrm{a}} /(21 \pm 0.3)^{\mathrm{b}}$ & $0.512^{\mathrm{a}} /(26 \pm 0.58)^{\mathrm{b}}$ & $0.128^{\mathrm{a}} /(25 \pm 0.0)^{\mathrm{b}}$ & $0.128^{\mathrm{a}} /(20 \pm 0.82)^{\mathrm{b}}$ \\
\hline Microccus. spp (1) & $0.00025^{\mathrm{a}} /(23 \pm 0.5)^{\mathrm{b}}$ & $0.008^{\mathrm{a}} /(17 \pm 0.0)^{\mathrm{b}}$ & $0.512^{\mathrm{a}} /(38 \pm 0.24)^{\mathrm{b}}$ & $0.512^{\mathrm{a}} /(20 \pm 0.5)^{\mathrm{b}}$ & $0.004^{\mathrm{a}} /(23 \pm 0.01)^{\mathrm{b}}$ \\
\hline Microccus. spp (2) & $0.001^{\mathrm{a}} /(18 \pm 0.6)^{\mathrm{b}}$ & $0.032^{\mathrm{a}} / \pm(18 \pm 0.59)^{\mathrm{b}}$ & $0.512^{\mathrm{a}} /(36 \pm 0.53)^{\mathrm{b}}$ & $0.00025^{\mathrm{a}} /(25 \pm 0.54)^{\mathrm{b}}$ & $0.0002^{\mathrm{a}} /(33 \pm 0.31)^{\mathrm{b}}$ \\
\hline Koc.varians $/$ rosea $(1)$ & $0.002^{\mathrm{a}} /(13 \pm 0.67)^{\mathrm{b}}$ & $0.032^{\mathrm{a}} /(25 \pm 0.53)^{\mathrm{b}}$ & & $0.032^{\mathrm{a}} /(21 \pm 0.0)^{\mathrm{b}}$ & $0.512^{\mathrm{a}} /(23 \pm 0.35)^{\mathrm{b}}$ \\
\hline Koc.varians $/$ rosea $(2)$ & $0.004^{\mathrm{a}} /(20 \pm 0.2)^{\mathrm{b}}$ & $0.016^{\mathrm{a}} /(19 \pm 0.4)^{\mathrm{b}}$ & $0.512^{\mathrm{a}} /(32 \pm 0.42)^{\mathrm{b}}$ & - & - \\
\hline S. capitis & $0.002^{\mathrm{a}} /(21 \pm 0.32)^{\mathrm{b}}$ & $0.008^{\mathrm{a}} /(15 \pm 0.0)^{\mathrm{b}}$ & & - & - \\
\hline
\end{tabular}

$\mathrm{a}=\operatorname{MIC}(\mu \mathrm{g} / \mathrm{ml}) \mathrm{b}=$ Diameter Zone $(\mathrm{mm} \pm \mathrm{SD})-=$ no effect.

Table 4. Minimum Inhibitory Concentration (MIC) of some Antibiotics for Enterobacteriaceae Isolated from Foods

\begin{tabular}{|c|c|c|c|c|c|}
\hline \multirow{2}{*}{ Species } & \multicolumn{5}{|c|}{$\operatorname{MIC}(\mu \mathrm{g} / \mathrm{ml})^{\mathrm{a}} /$ Diameter zone $(\mathrm{mm})^{\mathrm{b}}$} \\
\hline & Gentamicin & Tetracycline & Cephalosporin & Streptomycin & Penicillin \\
\hline E. coli (NCTC 9001) & $0.002^{\mathrm{a}} /(20 \pm 0.0)^{\mathrm{b}}$ & $0.032^{\mathrm{a}} /(23 \pm 0.2)^{\mathrm{b}}$ & $0.512^{\mathrm{a}} /(22 \pm 0.19)^{\mathrm{b}}$ & $0.004^{\mathrm{a}} /(18 \pm 0.1)^{\mathrm{b}}$ & $0.128^{\mathrm{a}} /(14 \pm 0.0)^{\mathrm{b}}$ \\
\hline K. pneumoniae (1) & $0.002^{\mathrm{a}} /(19 \pm 0.0)^{\mathrm{b}}$ & $0.032^{\mathrm{a}} /(16 \pm 0.11)^{\mathrm{b}}$ & $0.256^{\mathrm{a}} /(17 \pm 0.0)^{\mathrm{b}}$ & $0.008^{\mathrm{a}} /(17 \pm 0.01)^{\mathrm{b}}$ & $\left.0.256^{\mathrm{a}} / 15 \pm 0.2\right)^{\mathrm{b}}$ \\
\hline K. pneumoniae (2) & $0.002^{\mathrm{a}} /(17 \pm 0.24)^{\mathrm{b}}$ & $0.064^{\mathrm{a}} /(17 \pm 0.0)^{\mathrm{b}}$ & $0.512^{\mathrm{a}} /(21 \pm 0.2)^{\mathrm{b}}$ & $0.004^{\mathrm{a}} /(14 \pm 0.0)^{\mathrm{b}}$ & $0.256^{\mathrm{a}} /(13 \pm 0.1)^{\mathrm{b}}$ \\
\hline E. aerogenes & $0.002^{\mathrm{a}} /(17 \pm 0.33)^{\mathrm{b}}$ & $0.128^{\mathrm{a}} /(19 \pm 0.4)^{\mathrm{b}}$ & - & $0.008^{\mathrm{a}} /(12 \pm 0.4)^{\mathrm{b}}$ & $0.256^{\mathrm{a}} /(18 \pm 0.03)^{\mathrm{b}}$ \\
\hline E. sakazakii & $0.002^{\mathrm{a}} /(18 \pm 0.0)^{\mathrm{b}}$ & $0.128^{\mathrm{a}} /(18 \pm 0.13)^{\mathrm{b}}$ & - & $0.008^{\mathrm{a}} /(16 \pm 0.5)^{\mathrm{b}}$ & - \\
\hline Aero. hydrophila & $0.002^{\mathrm{a}} /(20 \pm 0.15)^{\mathrm{b}}$ & $0.032^{\mathrm{a}} /(19 \pm 0.2)^{\mathrm{b}}$ & $0.128^{\mathrm{a}} /(20 \pm 0.36)^{\mathrm{b}}$ & $0.008^{\mathrm{a}} /(20 \pm 0.14)^{\mathrm{b}}$ & $0.064^{\mathrm{a}} /(18 \pm 0.18)^{\mathrm{b}}$ \\
\hline E. cancerogenus & $0.0005^{\mathrm{a}} /(16 \pm 0.5)^{\mathrm{b}}$ & $0.004^{\mathrm{a}} /(19 \pm 0.0)^{\mathrm{b}}$ & $0.128^{\mathrm{a}} /(17 \pm 0.0)^{\mathrm{b}}$ & $0.004^{\mathrm{a}} /(15 \pm 0.22)^{\mathrm{b}}$ & $0.0128^{a} /(19 \pm 0.0)^{b}$ \\
\hline K. oxytoca & $0.004^{\mathrm{a}} /(23 \pm 0.23)^{\mathrm{b}}$ & $0.004^{\mathrm{a}} /(23 \pm 0.3)^{\mathrm{b}}$ & $0.032^{\mathrm{a}} /(21 \pm 0.20)^{\mathrm{b}}$ & $0.256^{\mathrm{a}} /(23 \pm 0.0)^{\mathrm{b}}$ & $0.128^{\mathrm{a}} /(19 \pm 0.5)^{\mathrm{b}}$ \\
\hline
\end{tabular}

$\mathrm{a}=\mathrm{MIC}(\mu \mathrm{g} / \mathrm{ml}), \mathrm{b}=$ Diameter Zone $(\mathrm{mm} \pm \mathrm{SD}),-$ = no effect. 
Table 5. The Susceptibility of Bacillus. spp Isolated from Various Infant Foods to some Antibiotics

\begin{tabular}{|c|c|c|c|c|c|c|c|c|c|c|c|}
\hline $\begin{array}{l}\text { Antimicrobial } \\
\text { Agent }\end{array}$ & $\begin{array}{l}\text { Brevi. } \\
\text { laterosporus }\end{array}$ & $\begin{array}{l}\text { Bacillus } \\
\text { spp. }\end{array}$ & $\begin{array}{l}\text { B. cereus } \\
\text { (1) }\end{array}$ & $\begin{array}{l}\text { B. cereus } \\
\text { (2) }\end{array}$ & $\begin{array}{l}\text { B. cereus } \\
\text { (3) }\end{array}$ & $\begin{array}{l}\text { Geobacillus } \\
\text { stearothermophi- } \\
\text { lus }\end{array}$ & $\begin{array}{l}\text { B. cereus } \\
\text { (4) }\end{array}$ & $\begin{array}{l}\text { B. cereus } \\
(5)\end{array}$ & $\begin{array}{l}\text { B. licheni- } \\
\text { formis }\end{array}$ & B. subtilis & $\begin{array}{l}\text { B. cereus } \\
(6)\end{array}$ \\
\hline $\begin{array}{l}\text { Penicillin G } 10 \\
\text { units }\end{array}$ & 9 (I) & $29(\mathrm{~S})$ & 8 (I) & $10(\mathrm{I})$ & $0(\mathrm{R})$ & $10(\mathrm{I})$ & 9 (I) & 8 (I) & $7(\mathrm{R})$ & $10(\mathrm{I})$ & 12 (I) \\
\hline $\begin{array}{l}\text { Streptomycin } \\
\quad(10 \mu \mathrm{g})\end{array}$ & $22(\mathrm{~S})$ & $26(S)$ & $21(\mathrm{~S})$ & $25(\mathrm{~S})$ & $20(\mathrm{~S})$ & $24(\mathrm{~S})$ & $25(\mathrm{~S})$ & $22(\mathrm{~S})$ & $20(\mathrm{~S})$ & $26(S)$ & $24(\mathrm{~S})$ \\
\hline $\begin{array}{l}\text { Erythromycin } \\
\qquad(15 \mu \mathrm{g})\end{array}$ & $30(\mathrm{~S})$ & $34(\mathrm{~S})$ & $29(\mathrm{~S})$ & $32(\mathrm{~S})$ & $27(\mathrm{~S})$ & $30(\mathrm{~S})$ & $31(\mathrm{~S})$ & $30(\mathrm{~S})$ & $28(\mathrm{~S})$ & $38(\mathrm{~S})$ & $21(\mathrm{~S})$ \\
\hline Ampicillin $(10 \mu \mathrm{g})$ & $10(\mathrm{R})$ & $30(\mathrm{~S})$ & $10(\mathrm{R})$ & $12(\mathrm{I})$ & $0(\mathrm{R})$ & $14(\mathrm{I})$ & $10(\mathrm{R})$ & $9 \mathrm{R})$ & $10(\mathrm{R})$ & $30(\mathrm{~S})$ & 12 (I) \\
\hline $\begin{array}{l}\text { Cephalothin } \\
\qquad(30 \mu \mathrm{g})\end{array}$ & $16(\mathrm{I})$ & $49(\mathrm{~S})$ & $14(\mathrm{R})$ & $14(\mathrm{R})$ & $18(\mathrm{~S})$ & 17 (I) & $15(\mathrm{I})$ & $14(\mathrm{R})$ & $14(\mathrm{R})$ & $46(S)$ & $17(\mathrm{I})$ \\
\hline $\begin{array}{l}\text { Chloramphenicol } \\
\qquad(30 \mu \mathrm{g})\end{array}$ & $25(\mathrm{~S})$ & $37(\mathrm{~S})$ & $25(\mathrm{~S})$ & $24(\mathrm{~S})$ & $8(\mathrm{R})$ & $34(\mathrm{~S})$ & $35(\mathrm{~S})$ & $24(\mathrm{~S})$ & $21(\mathrm{I})$ & $35(\mathrm{~S})$ & $27(S)$ \\
\hline $\begin{array}{l}\text { Kanamycin } \\
\quad(10 \mu \mathrm{g})\end{array}$ & $25(\mathrm{~S})$ & $30(\mathrm{~S})$ & $19(\mathrm{~S})$ & $25(\mathrm{~S})$ & $20(\mathrm{~S})$ & $26(S)$ & $25(\mathrm{~S})$ & $19(\mathrm{~S})$ & $19(\mathrm{~S})$ & $30(\mathrm{~S})$ & $27(S)$ \\
\hline $\begin{array}{l}\text { Nalidixic acid } \\
\qquad(30 \mu \mathrm{g})\end{array}$ & $12(\mathrm{R})$ & $23(S)$ & $20(\mathrm{~S})$ & $22(\mathrm{~S})$ & $18(\mathrm{I})$ & $14(\mathrm{I})$ & $21(\mathrm{~S})$ & $19(\mathrm{~S})$ & $17(\mathrm{I})$ & $21(\mathrm{~S})$ & $11(\mathrm{R})$ \\
\hline $\begin{array}{l}\text { Bacitracin } \\
\text { (10 units) }\end{array}$ & $11(\mathrm{R})$ & $10(\mathrm{R})$ & $18(\mathrm{~S})$ & $21(\mathrm{~S})$ & $0(\mathrm{R})$ & $12(\mathrm{R})$ & $13(\mathrm{R})$ & $19(\mathrm{~S})$ & $22(\mathrm{~S})$ & $13(\mathrm{R})$ & $9(\mathrm{R})$ \\
\hline $\begin{array}{c}\text { Tetracycline } \\
(30 \mu \mathrm{g})\end{array}$ & $27(\mathrm{~S})$ & $21(\mathrm{~S})$ & $18(\mathrm{I})$ & $20(\mathrm{~S})$ & $13(\mathrm{R})$ & $27(\mathrm{~S})$ & $25(\mathrm{~S})$ & $22(\mathrm{~S})$ & 15 (I) & $20(\mathrm{~S})$ & $30(\mathrm{~S})$ \\
\hline $\begin{array}{l}\text { Gentamicin } \\
\quad(10 \mu \mathrm{g})\end{array}$ & $23(\mathrm{~S})$ & $36(\mathrm{~S})$ & $22(\mathrm{~S})$ & $21(\mathrm{~S})$ & $20(\mathrm{~S})$ & $25(\mathrm{~S})$ & $22(\mathrm{~S})$ & $22(\mathrm{~S})$ & $22(\mathrm{~S})$ & $29(\mathrm{~S})$ & $24(\mathrm{~S})$ \\
\hline
\end{tabular}

$\mathrm{R}=$ Resistance, $\mathrm{I}=$ Intermediate, $\mathrm{S}=$ susceptible.

Table 6. The Susceptibility of Staphylococcus spp. and Micrococcus spp. Isolated from Various Infant Foods to some Antibiotics

\begin{tabular}{|c|c|c|c|c|c|c|c|c|c|c|}
\hline $\begin{array}{c}\text { Antimicrobial } \\
\text { Agent }\end{array}$ & \multicolumn{10}{|c|}{ Zone Diameter (mm) } \\
\hline $\begin{array}{c}\text { Penicillin G } 10 \\
\text { units }\end{array}$ & $40(\mathrm{~S})$ & 15 (I) & $25(\mathrm{~S})$ & $32(\mathrm{~S})$ & $45(S)$ & $30(\mathrm{~S})$ & $0(\mathrm{R})$ & $0(\mathrm{R})$ & $29(\mathrm{~S})$ & $0(\mathrm{R})$ \\
\hline $\begin{array}{l}\text { Erythromycin } \\
\quad(15 \mu \mathrm{g})\end{array}$ & $30(\mathrm{~S})$ & $37(\mathrm{~S})$ & $35(\mathrm{~S})$ & $31(\mathrm{~S})$ & $45(\mathrm{~S})$ & $35(\mathrm{~S})$ & $10(\mathrm{R})$ & $13(\mathrm{R})$ & $28(\mathrm{~S})$ & $0(\mathrm{R})$ \\
\hline Ampicillin $(10 \mu \mathrm{g})$ & $40(\mathrm{~S})$ & $25(\mathrm{~S})$ & $24(\mathrm{~S})$ & $32(\mathrm{~S})$ & 49 (S) & $32(\mathrm{~S})$ & 13 (I) & 14 (I) & $25(\mathrm{~S})$ & $11(\mathrm{R})$ \\
\hline Cephalothin $(30 \mu \mathrm{g})$ & $40(\mathrm{~S})$ & $28(\mathrm{~S})$ & $26(S)$ & $30(\mathrm{~S})$ & $55(\mathrm{~S})$ & $57(\mathrm{~S})$ & $18(\mathrm{~S})$ & $29(\mathrm{~S})$ & $25(\mathrm{~S})$ & $6(\mathrm{R})$ \\
\hline $\begin{array}{l}\text { Nalidixic acid } \\
\quad(30 \mu \mathrm{g})\end{array}$ & $30(\mathrm{~S})$ & 17 (I) & $19(\mathrm{~S})$ & $25(\mathrm{~S})$ & $30(\mathrm{~S})$ & $24(\mathrm{~S})$ & $21(\mathrm{~S})$ & $22(\mathrm{~S})$ & $0(\mathrm{R})$ & $20(S)$ \\
\hline $\begin{array}{l}\text { Bacitracin } \\
\text { (10 units) }\end{array}$ & $24(\mathrm{~S})$ & $13(\mathrm{R})$ & $19(\mathrm{~S})$ & $13(\mathrm{R})$ & $24(\mathrm{~S})$ & $12(\mathrm{R})$ & $0(\mathrm{R})$ & $0(\mathrm{R})$ & $21(\mathrm{~S})$ & $0(\mathrm{R})$ \\
\hline $\begin{array}{l}\text { Tetracycline } \\
\quad(30 \mu \mathrm{g})\end{array}$ & $30(\mathrm{~S})$ & $30(\mathrm{~S})$ & $30(\mathrm{~S})$ & $24(\mathrm{~S})$ & $25(\mathrm{~S})$ & $24(\mathrm{~S})$ & $19(\mathrm{~S})$ & $20(\mathrm{~S})$ & $24(\mathrm{~S})$ & $20(S)$ \\
\hline Gentamicin $(10 \mu \mathrm{g})$ & $22(\mathrm{~S})$ & $30(\mathrm{~S})$ & $26(S)$ & $30(\mathrm{~S})$ & $35(\mathrm{~S})$ & $31(\mathrm{~S})$ & $22(\mathrm{~S})$ & $22(\mathrm{~S})$ & $19(\mathrm{~S})$ & $20(\mathrm{~S})$ \\
\hline
\end{tabular}

$\mathrm{R}=$ Resistance, $\mathrm{I}=$ Intermediate, $\mathrm{S}=$ susceptible. 
Table 7. The Susceptibility of Enterobacteriaceae Isolated from Various Infant Foods to some Antibiotics

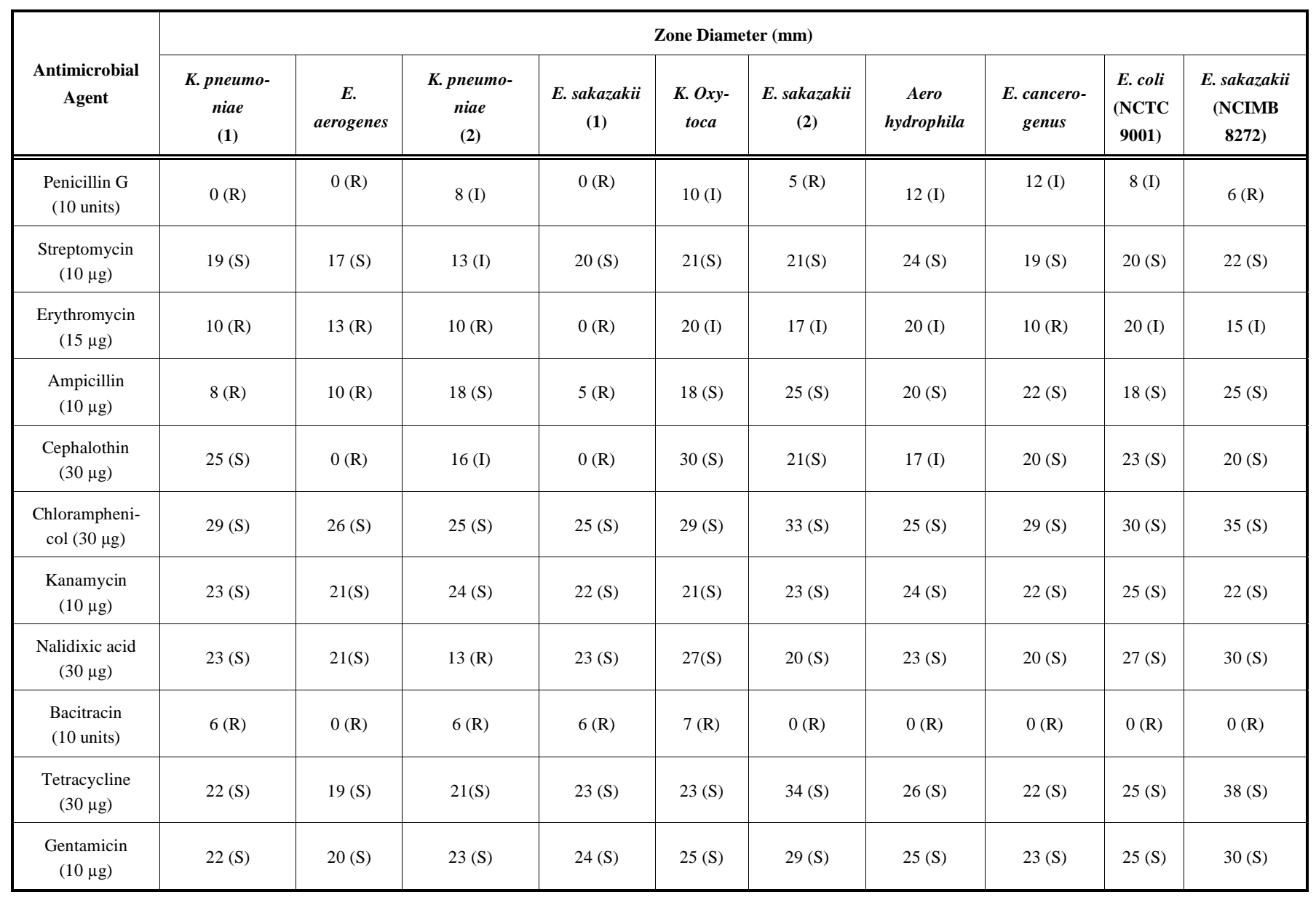

$\mathrm{R}=$ Resistance, $\mathrm{I}$ = Intermediate, $\mathrm{S}=$ susceptible.

Antibiotic resistance profiles of the isolates are shown in Tables 5 to 7. The percentage resistance of Enterobacteriaceae was $100 \%$ with bacitracin, $50 \%$ erythromycin and penicillin, $30 \%$ ampicillin, $20 \%$ cephalosporin and $10 \%$ nalidixine acid. Cameiro et al. [35] reported that $33 \%$ of Enterobacteriaceae isolated from 18 infant formula samples were resistance to ampicillin, amoxicillin/ clavulanic acid, cefoxitin and cephalotin. The percentage resistance of Bacillus spp was $54.5 \%$ ampicillin, $63.6 \%$ bacitracin, $36.4 \%$ cephalosporin, while $18.2 \%$ was resistant to penicillin and nalidixic acid (Table 5). The percentage resistance by Staphylococcus spp. was $60 \%$ bacitracin and $30 \%$ penicillin and erythromycin (Table 6). The typed strain was susceptible to all antibiotics tested. Antibiotic resistance among the Enterobacteriaceae family varied (Table 7). Enterobacteriaceae, Staphylococcus spp. and Bacillus spp. strains were highly susceptible $(100 \%)$ to chloramphenicol, kanamycin, gentamicin and streptomycin. These results indicate that there is a considerable variation in susceptibility depending on the species. In most cases there were some antibiotics such as tetracycline, gentamicin, kanamycin and nalidixine acid which were highly active against Bacillus spp., Staphylococcus spp. and also active against Enterobacteriaceae.

\section{CONCLUSION}

Bacterial contamination is of the major concern since they tend to proliferate once a feed in reconstituted with wa- ter under warm environmental conditions. Also most isolated strains were resistance to some antibiotic agents such as cephalosporin, bacitracin and penicillin. Many of the locally produced infant foods investigated in this study are still produced by small to medium scale manufacturers whose premises, food processing and quality of ingredients may lack a thorough food safety protocol and quality assurance systems in the preparation and/or manufacture of these infant foods. Application of Hazard Analysis Critical Control Point (HACCP) system in the manufacturing processes would improve the quality of such products. An important aspect of the study, yet to be undertaken, is the mycological profile and presence of mycotoxins in the infant food especially when stored under simulated environmental conditions.

\section{ACKNOWLEDGMENTS}

SM gratefully acknowledges financial support from the Libyan Embassy, London for research studentship.

\section{REFERENCES}

[1] Michanie A, Frank L, Avarez P, Olivo A. Critical control points for food prepared in households in which babies had Salmonella. Int J Food Microbiol 1987; 5: 337-54.

[2] Lai K. Enterobacter sakazakii infection among neonates, children, and adults. Medicine (Baltimore) 2001; 80: 113-22.

[3] Schocken-Iturrino RP, Carneiro MC, Kato E, Sorbara JO, Rossi OD, Gerbasi LE. Study of presence of the spore of Clostridium botulinum in honey in Brazil. FEMS Immun Med Microbiol 1999; 24: $379-82$. 
[4] Razzazi-Fazeli E, Noviandi C, Porasuphatana A, Bohm J. A survey of aflatoxins B1 and total aflatoxins contamination in baby food, peanut and products sold at retail in Indonesia analyzed by ELISA and HPLC. Mycotoxins Res 2004; 20: 51-8.

[5] Fone M, Larry R, Michael P, et al. Survival and growth of Shigella flexneri, Salmonella enterica serovar Enteritidis, and Vibrio choleraeol in reconstituted infant formula. Am J Trop Med 2002; 66: 782-6.

[6] Lehner A, Tasara T, Stehan R. 16S rRNA gene based analysis of Enterobacter Sakazakii from different sources and development of a PCR as identification. BMC Microbiol 2004; 4: 43.

[7] Schmitt N, Bowmer EJ, Willoughby BA. Food poising outbreak attributed to Bacillus cereus. Can J Public Health 1976; 67: 418-22.

[8] Muytjens HL, Roelofs-Willemse H, Jasper GH. Quality of powder substitutes for breast milk with regad to members of the family Enterobacteriaceae. J Clin Microbiol 1988; 26: 743-46.

[9] Iversen C, Forsythe S. Isolation of Enterobacter sakazakii and other Enterobacteriaceae from powdered infant formula milk and related products. Food Microbiol 2004; 21: 771-6.

[10] International Baby Food Action Network (IBFAN). Urges for better information on infection risks related to baby food. The world Health Assembly held its $58^{\text {th }}$ meeting from 16-25 May 1998 in Geneva. Babies cannot wait 2005 Available at: http://www.gifa.org

[11] Vasavada PC. Testing Enterobacter sakazakii: The quest for Testing 2005. Available at: File://E:I Food safety Magazine.htm

[12] Nazaowec M, Farber J. Enterobacter sakazakii: a review. Int J Food Microbiol 1998; 34: 103-13.

[13] Health Protection Scotland (HPS. HPS weekly reports) Warning on Ugandan baby food.http//www.documents.hps.scot.nhs 2007.

[14] Roberts D, Greenword M, Hooper W. Confirmatory biochemical tests. Practical food microbiology: methods for the examination of food for micro-organisms of public health significance. 3rd ed: Blackwell Publishing 2004.

[15] Samson R, Hoekstra E, Frisvad J, Filtenborg O. Introduction to Food Borne Fungi. $6^{\text {th }}$ ed. Centraalbureau voor Schimmelcultures: Utrecht Netherlands 2002.

[16] NCCLS Document M2.A5. Performance standards for Antimicrobial Disk Susceptibility Tests-Fifth ed. Approved Standard 1993; vol. 13: p. 24.

[17] Carmen D, Rosa M, Borobio M. Application of a spectrophotometric method for determination of post-antibiotic effect and comparison with viable counts in agar. J Antimicrob Chemother 2001; 47: 391-8.

[18] Institute of Food Science and Technology (IFST). Development and use of Microbiological criteria for foods: (ISBN 0905367162) London 1991.

[19] Becker H, Schaller G, Wiess W, Terplan G. Bacillus cereus in infant foods and dried milk products. Int J Food Microbiol 1994; 23: $1-5$.
[20] Kramer JM, Gilbert JL. Bacillus cereus and others Bacillus species. Food-borne Bacterial Pathogens. Marcel Dekker: New York 1989; pp. 21-70.

[21] Rowan N, Anderson J, Anderton A. The bacteriological quality of Hospital-prepared infant feeds. J Hosp Infect 1997; 36: 259-67.

[22] Jaquette CB, Beuchat LR. Survival and growth of psychrotrophic Bacillus cereus in dry and reconstituted infant rice cereal. J Food Prot 1998; 61: 1629-35.

[23] Juan ER, Jose MB, Manuel RG, Mari OR. Prevalence of Bacillus cereus in dried milk products used by Chilean School Feeding Program. Food Microbiol 2007; 24: 1-6.

[24] Chantal M, Martina WR, Leon G, Gorris M, Olivier G, Mike S. Occurrence of Enterobacter sakazakii in food production environments and households. Lancet 2004; 363. Available at: http//.www.thelancet.com

[25] In-tveld PH, Soentoro PSS, Delfgou-Van Asch EHM, Notermans S. Influence of reconstitution on isolation and enumeration of Listeria monocytogenes from milk powder used for reference samples. J Food Protect 1991; 54: 124-6.

[26] Van Acker J, De Smet F, Muyldermans G, Anne Naessens A, Lauwers S. Outbreak of necrotizing enterocolitis associated with Enterobacter sakazakii in powdered milk formula. J Clin Microbiol 2001; 39: 293-7.

[27] Benda P, Vyletelova M. Staphylococcus aureus in bulk milk samples. Vet Med (Praha) 1995; 40: 221-6.

[28] Silvia M, Frank LB, Persia A, Auria BO. Critical control points for foods prepared in households in which babies had Salmonellosis Int J Food Microbiol 1987; 5: 337-54.

[29] Sugimoto Y, Suzuki A, Ito A, et al. Characterization of microflora in raw milk and powdered milk. J Antibact Antifung Agents 2004; 32: $243-50$.

[30] Stephen JF. Enterobacter sakazakii and other bacteria in powdered infant milk formula. Matern Child Nutr 2005; 1: 44-50.

[31] Letertre C, Perelle F, Fach P. Identification of a new putative enterotoxin SEU encoded by the egc cluster of Staphylococcus aureus. J Appl Microb 2003; 95: 38-43.

[32] Sabath LD, Abraham EP. Cephalosporinase and penicillinase activity of Bacillus cereus. Antimicrob Agents Chemother 1996; 392-7.

[33] Dieter A. Global antibiotic resistance in Streptococcus pneumoniae. J Antimicrob Chemother 2002; 50: 1-5.

[34] Cloete T. Resistance and mechanisms of bacteria to antimicrobial compound. Hyg Disinfect 2003; 51: 277-82.

[35] Cameiro LA, Silva AP, Merquior VL, Oueiroz M. Antimicrobial resistance in Gram-negative bacilli isolated from infant formulas. FEMS Microbiol Lett 2003; 228: 175-9.

(c) Shadlia-Matug et al.; Licensee Bentham Open.

This is an open access article licensed under the terms of the Creative Commons Attribution Non-Commercial License (http://creativecommons.org/licenses/by-nc/3.0/) which permits unrestricted, non-commercial use, distribution and reproduction in any medium, provided the work is properly cited. 